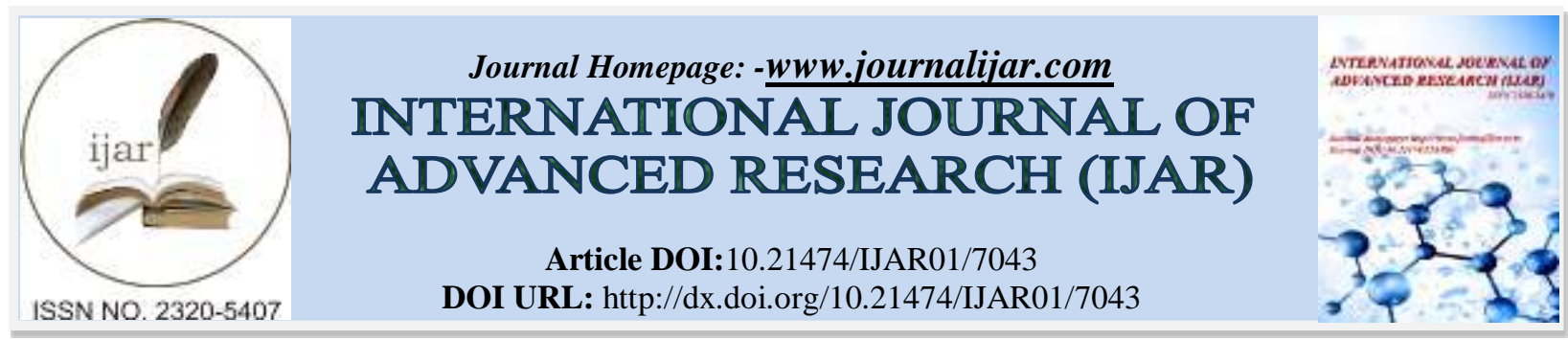

RESEARCH ARTICLE

\title{
COMMUNITY-MANAGED FORESTRY IN NEPAL: A REVIEW OF DOCUMENTARY FINDINGS.
}

Prabhat Bhattarai.

UNEP TONGJI IESD, College of Environmental Science, Tongji University, 1239 Siping Road, Shanghai, 200092, P.R. China.

\section{Manuscript Info}

Manuscript History

Received: 06 March 2018

Final Accepted: 08 April 2018

Published: May 2018

Keywords:-

Community Forest Management,

Biodiversity, Women empowerment,

Good Governance, Sustainable

Development, Wildlife Protection.

\section{Abstract}

The review of 50 articles dealing with community forestry in Nepal provide with evidences of the significant influence of community forestry on several aspects of people's life and development. The concept of the community forestry that underscores the value of institutional flexibility, community autonomy and participatory, itself is the a key to influence on the successes of community forest in the context of Nepal. The definition of the success of the community forestry is attributed to the impact it has created on biodiversity conservation, improvement of rural livelihood and welfare, empowerment of women and disadvantages people, contribution to sustainable development, increase in supply of forest product, wildlife protection, control on forest fire, grazing and over exploitation, its contribution to good governance and to local democracy. This paper analyses participatory approach on forest resource management and provides with sufficient evidence towards the success of community forest management practices in Nepal.

Several studies on community forest management found that the major factor of forest development is the formulation of user's group to facilitate utilization of available forest resources with collective interest. Finding shows that nationally and internationally defined variables, indicators and principles have not been significantly practical in Nepal due to scientific and technical reasons. However, community forest management is the most successful concept implemented by the Government of Nepal which is one of the widespread and rapidly growing policy tool over the period where the community members are actively involved in the utilization of forest resources management and take benefits for the collective interest.

Copy Right, IJAR, 2018,. All rights reserved.

\section{Introduction:-}

\section{Background:-}

The resource base in Nepal: country background:-

Nepal, a landlocked country situated between two giant neighboring countries India and China that covers 1,47,181 $\mathrm{km}$ square land with about 27 million population living in. (CBS, 2011). The Country is divided in three 
geographical parts namely Terai, Pahad \& Himalaya region. Climate varies from subtropical conditions to alpine from negative degree centigrade to 45 degree centigrade.

Nepal's forest occupies a total of 6.61 million ha, which is $44.74 \%$ (including other woodland, 0.65 million ha or $4.38 \%$ ) of the total area. Forest land covers 5.96 million ha. Or $40.36 \%$. Similarly, $37.8 \%$ is occupied by Madhya pahadi, $32.25 \%$ covered by Himali region, $23.04 \%$ covered by Chure and $6.9 \%$ area is covered by Tarai Madhes. (DOF, 2017).

In practice, there are six categories of forest management in Nepal shown as below. Forest classification, management objectives and area coverage

\begin{tabular}{|l|l|l|}
\hline Categories & Management objectives & Are coverage (ha, 000) \\
\hline $\begin{array}{l}\text { Government managed } \\
\text { (National forest) }\end{array}$ & Production of forest product & 3,90227 \\
\hline Community managed & $\begin{array}{l}\text { protection of forest and utilization for the } \\
\text { collective interest }\end{array}$ & 1200 \\
\hline Protected & $\begin{array}{l}\text { protection of wildlife, biodiversity and } \\
\text { environment }\end{array}$ & 711 \\
\hline Leasehold & $\begin{array}{l}\text { Rehabilitation of forest production of forest } \\
\text { products }\end{array}$ & 41.73 \\
\hline Private & Protection of forest & 2.3 \\
\hline
\end{tabular}

(Bhattarai, 2016)

The major objective of community forest is to protect forest and utilization of resources by the communities for collective interest. At present 200 forests are managed by the community and 28 are managed by participatory approach and only seven are managed under Government as national forest.

Forest has significant impact to the people's life specially for livelihood. Source of $78 \%$ of the energy and $68 \%$ food is the forest. (Maharjan, 2004). Other main resources that are met from the forests are means of livestock farming, inputs for agriculture and supply of timber and non-timber products.(G.C. Dhruba et.al., 2016). In the previous researches, there are several terms such as joint forest management, community-based forest management, collaborative forest management, community forestry which are used to denote community forest management. This paper uses the term Community Forest Management (CFM) as defined by the government which is approved by the government and are managed by the the local community for social and economic benefits with sustainable management of the forest resources. The democratic movement in Nepal in 1990, improved travel opportunities, availability of means of communication, educational level have a great contribution to the ability of different actors to participate more effectively in community forestry. (Pokhrel et. al., 2007). Hence, the community forestry program was implemented in 1993 after long debates on natural resources management, however, the concept was built up in 1978. As a result, new policy has taken over the sustainable management of the forests, influencing local, regional and national forestry development programs, policy and legislation including Forest Act (1993), Forest Regulation (1995), Guidelines for Community Forestry Inventory (2004) and the Guidelines for Community Forestry Development Program (2009). The main objective of these policies is to increase local community's participation in decision making process to access rights on benefits of the forest by managing available resources. It plays effective role in people's livelihood and in managing forest resources with people's participation addressing the environmental, socioeconomic and political problems.(Acharya et. al., 2006). (Pokharel et. al., 2007).

Community forest is a state-owned forest handed over to local people for the development, conservation and usage of resources in pursuit of their collective interest. (Pandey et. al., 2016). Under this plan, community applies to govern and manage forest resources with the support of government experts for an extendable 10 year concession. It implies local people's involvements in decision making and control of revenue benefits and forest products as well as increase local value-added manufacturing with ecological integrity of the forest ecosystem. (MOF, 2016). Community people are the effective managers of forests, if they are given by right institutional arrangements and conditions as it is participatory approach to manage resources (Olive et. al., 2003). This concept addresses problems and needs of the communities and gives solution with scientific and technical knowledge. (Pagdee et. al., 2006). It is a component of national forests, most of these forests are degraded or have been recently planted by the government or by local communities. (Wagley \& Ojha, 2002). The relationship between two successful factors of the community forest as community and resources can be developed with well-defined property rights and local institutional settings 
which local people's expectations of resources are addressed. (Bromley, 1989). (Pagdee et. al., 2006). Hence, the land tenure, benefit sharing arrangement and grassroots managements are the three pillars that support the integration of rural development and forest management. (Liu \& Innes, 2015). Community forest management is the management process of people and available forest resources simultaneously where people develop plan and policy for the better outcomes through the user's group with aiming to reduce deforestation, maintain biodiversity and improving local human welfare, poverty alleviation to the global environmental benefits. Community Forestry User's Group (CFUG) is a legally registered group of those desirous to utilize the forest products by developing and conserving such forests for the collective interest as it is self-governing, eternal and corporate body. (Forest Act, 1993). It constructs community forest nurseries, establish plantations, protect and manage natural forests in sustainable manner and establish forest-based enterprises. (Pokharel et. al., 2007). The success of community forestry has released remarkable forces of social participation. Community people represent an effective local development institution increasingly involved in wider community development activities, often networking with government and non-government groups. (Oliver et. al., 2003).

Previous researchers concluded that this is the most successful plan implemented by the government of Nepal, as it is one of the widespread and rapidly growing policy tool over the period, where the community members actively involve in the utilization of forest resources management and take benefits for the collective interest. This paper examines the development and success of community forest management in the Nepalese context and identifies key lessons learned and way forward based on previous researches, academic literature, project documents and government reports.

Current status of community forest management in Nepal

\begin{tabular}{|l|l|}
\hline Particulars & Remarks \\
\hline Total land area of Nepal & 1.47 Million ha \\
\hline Total forest area & 6.61 Million ha \\
\hline Potential for community forest management & 3.96 Million ha \\
\hline Area handed over to CFUGs & 1.81 Million ha \\
\hline Area managed by women & 52906 ha \\
\hline Number of CFUGs & 19,361 \\
\hline Number of Women FUGs & 1072 \\
\hline Number of beneficiary household & $24,61,594$ \\
\hline
\end{tabular}

(DOF, 2017)

The trend of the forest degradation has decreased and covered by forest is grown to $44.78 \%$ from $29 \%$ after handing over to the communities. (Neupane et. al., 2017). (Kanel et. al., 2004). As it is one of the priority program, only 30\% area is managed by the community out of $60 \%$ of potentiality. The 1,813,478 hectares of national forest have been handed over to 19,361 community forest user's group with 1072 women being involved in the committee as members. From this forestry management program, 35\% of the population of the country and 24,61,549 households have been benefited. (DOF, 2017).

\section{Evaluation of community forest management policy, programs development and legislation:-}

Forest management concept began in Nepal in 1880s after the establishment of forest inspection and timber offices throughout the country. (Harini et. al., 2005). More likely, the organized concept was developed after 1955 with the establishment of National Planning Commission. As a result, the five year national plan started since 1956, introduced forestry plan and development strategies. The main objectives of the forestry plan was to meet people's basic needs for forest products, protect land, environment, inherent resources as well as to contribute to the national economic growth. Hence, the private forest nationalization act is promulgated in 1957, aiming to control all forests under the government.

The first national plan addressed the forest policy regarding the extension and development of forest organizations as well as forest services, implementation of forest survey and other research programs. Similarly, one of the main priorities of the second five year plan was scientific management and conservation of the forests, inventory management of forest resources and development of other forest research activities. The third year plan also aimed to provide forest services to the surrounded people by involving them in afforestation as well as developing forest infrastructures in all 75 districts in Nepal. 
However, the fourth five year plan hasn't prioritized forest sector, but focused to soil conservation, watershed management, forest research and development program under agriculture policy. As a result of forestry development activities such as botanical survey, wildlife conservation, institutional reforms, human resources development in the forest sector were initiated.

The forest development and policy making strategies were continued to tenth five year plan. Up to this period, several strategies and decisions have been made by the government including handover of the forest management to the community, formulation of community forestry user's group to utilize the forest resources through collective interest.

At present, the main objective of the government of Nepal through Ministry of Forest and Soil Conservation (MFSC) is to provide management for the sustainable development of the forest and water sector, and to manage the forest, herbs, land and biodiversity aiming to decrees the poverty rate by giving forest management opportunities to the local people. The five departments; the Department of Forests, the Department of National Parks and Wildlife Conservation, the Department of Forest Survey and Research, the Department of Soil Conservation and Watershed Management and the Department of Plant Resources as well as five regional forest directorates and four parasternal organizations are working in all 75 districts under MFSC. These development trends in forest plan and policies resulted into delivering participatory tools in forestry management strategies. There are various incentives and subsidies are developed to facilitate and mobilize people in forestry development programs. (Wagley \& Ojha, 2002).

\section{Success factors:-}

Various indicators are used to measure success of the CFM. Resources available from forest for fuel, fodder, timber and non-timber products, increase in forest land, greenery, increase in forest trees, decrease in degradation, control of forest fire and wildlife hunting, availability of water sources are the direct benefits to define success of CFM. In depth, several factors have been identified that led to the success of CFM by previous researchers. Such factors are community size (Wade, 1988). socio- economic heterogeneity (Baland and Platteau, 1996). institutional setting, and property rights structure. (Hanna and Munasinghe, 1995a; 1995b). (Baland and Platteau, 1999). (Ostrom 1999). (Pye, Smith et. al., 1994). Similarly, (Pokharel and Subedi, 2007) applied other factors in CFM as; access to fuel wood, fodder, timber, uses of compost, incidence of forest fires, amount if community fund, women participation.

After reviewing 31 articles on community forestry, (Pagdee et. al., 2007) summarized the success of CFM depends on property rights, effective institutional arrangements and community interest and incentives. These all have direct impact on human ecosystem including ecological, social and economic aspect. Thus CFM success is associated with several issues and it has started contributing towards the country's development efforts.

\section{Research methodology:-}

As a review article, this study uses two main sources of data. The first source of data used is information published by the ministry of finance, ministry of forest and soil conservation, department of forest, district forest offices, central bureau of statistics in Nepal. Similarly, the second source of data consists the institutions, previous research, journal articles, published books and the tools used by government of Nepal and other offices that are related to success of the community forestry program.

\section{Discussions and results:-}

Community forestry is essentially about management of surrounding communities and forest resources. For sustainable management of community, CFUGs must also be capable of implementing the operational plans that they develop, whether by themselves or with assistance from others. (Dahal \& Cao, 2015). The direct contribution of the community forestry is to facilitate forest products/services to the community. The CFM includes agroforestry, livestock grazing, forest utilization, and traditional forest practices. (Adcharaporn et. al., 2006). This study reviewed 40th articles, discussed community forestry including management outcomes and factors that lead to the success, management practices and problems, and features of Nepali community forestry including forest property rights, institutional settings, forest and community sizes, socioeconomic information, forest classification etc. Institutional flexibility, communities autonomy and local's decision making authority are the curial variables of the successful community forestry. (Harini et. al., 2006). Hence, the result from the previous researchers on success of community forestry are summarized as follows. 


\section{Biodiversity conservation:-}

A study on Community forest management supports on biodiversity with evidences from two community forests of Nepal (Acharya, 2004). revealed that community forestry program supports on prohibition to wildlife hunting, forest fire and grazing control, forest encroachment control, conservation of soil erosion prone area and conservation of water source area, construction of irrigation canal for local development. Similarly, (Shrestha et. al., 2010). argued that community forest management program is the foundation of biodiversity conservation by reversing the trend of deforestation and increasing regeneration. They added forest area the main source of many eco-system, soil conservation, nutrient cycling, climate regulation as well as sources of timber and non-timber. The total carbon from Nepal's forest including live, dead standing, dead wood and below ground biomass, forest soils and litter and debris was estimated 176.95 ha which is 1,054.97 million tons. (MFSC, 2015).

\section{Women empowerment:-}

Several studies on community forest by women perspective conclude that one of the great benefits of community forestry is women empowerment. Since, 31.6\% women are members of CFUGs (FECOFUN, 2070). and 52,906 ha, forest area is handed over to 1072 women forest user's group. (DOF 2017). A study on status of community forest and women (Adhikari, 2011). using participatory approach reveled that community forestry program increases selfesteem and self-confidence of women in the society. Also, they are capable to voice in public meeting, participate in decision making process and are aware of their rights after while engaging themselves in community forestry management activities. Women manage to collect forest products, fodder, fuel wood, bedding materials and grass as they are primarily responsible for house. (Acharya \& Gentle, 2006). Hence, they have good knowledge of certain forest resources as to how these products should be extracted and which species should be planted. (G.C. Dhurba et. al., 2016). Higher participation of woman in CFUGs as executive committee helps to decrease forest fires. (Leone, 2013).

\section{Sustainable development:-}

Sustainable development has been previously used and defined by different authors. It identifies the problems and needs and lead to the solutions of the communities members. Community forestry plan and policy was based on sustainability concepts to produce socially, economically and ecologically beneficial results (Dahal \& Cao, 2015). Several studies on community forest (Pokharel \& Nurse, 2004). (Dev O.P., et. al., 2003). emphasizes the positive incensement of natural, social, human, livestock, and financial capital through community forestry in Nepal. Similarly, community forestry is a way of transferring Sustainable Forest Management (Bhattacharya et. al., 2010). About one third of the CFUGs have made contribution to road and construction, half on education (Bhattarai, 2011). Some other researchers mentioned that community forestry is the government approved form of local communities, with an objective of providing natural, social, human and financial benefits while promoting the sustainable management of forest resources. (Klooster and Masera, 2000). (Padgee et. al., 2006). (Bhattacharya et. al., 2010). It has also contributed for children's education by providing scholarship for poor and infrastructural development support for school. Study on examination on effect of community-based management on changes in forest-resources condition (Tachibana et.al., 2007). with 101 randomly sampled forest in the middle hills of Nepal, shows that through the community forest management, forest fire occurrence has been reduced with external support. By controlling the possibility of self-selection in applying for support improved tree regeneration. Another study on community forestry program on revenue generating aspects says that revenue from the forest resources has synergetic effects on sustainable development. They use such revenue in social development activities such as making fences along forest boundaries, financing pro-poor program and constructing school buildings and village trails. (Poudel et. al., 2014).

\section{Rural livelihood and welfare:-}

Community forest management positively impacts on rural people's livelihood and welfare. Several studies in the field of CF, (Pokharel and Tumbahangphe, 1999). (Ojha, Cameron and Kumar, 2009). (Adhikari et. al., 2011). (Wagley et. al., 2003)., have focused on the participatory forest management concept as a requirement for the sustainable forest management and people's livelihood improvement. Local people are benefiting by fodder, manure, fuel wood, employment opportunities and other varieties of direct and indirect welfares from forest. (Maharjan). It helps to the members for income generating activities including vegetable farming, livestock, horticulture, fishery, bee-keeping, poultry farming (Pokharel and Charter, 2007). (Bhattarai, 2011). (MSFP, 2011). Members of the community forest users group are working as forest security, wood laborer, wood seller, fees collector, timber worker, nursery technicians and also involved in the production and sale of handicrafts through which they are generating income for livelihood. They extract fodder and grass for livestock, timber to build houses, fuel wood for 
household energy, wild food (vegetables and meat) as sources of food and generate income by other forest products. (Pandey et. al., 2016).

\section{Identification, demonstration and replication of poverty reduction practices:-}

Previous studies demonstrated significant impact of community forestry on poverty alleviation through their participation in CFUGs that positively supports for financial improvements and capacity building activities. CFUGs members are making money from various aspects of forest resources including selling of the forest products, collecting membership fees, fines and donation and utilizing the money by offering credit/loans facility to group members for income generating activities which creates self-employment opportunities to poorer households. Community member utilizes the money collected from membership fee and sales of forest products for microfinancing to the community members which aims to improve their standard of living. They provide soft loan for micro business such as knitting of clothes from the fiber of Allo plant to the poor to generate income. (Khanal and Kandel, 2004). These activities have significant contribution to poverty reduction.

\section{Contribution to good governance and local democracy:-}

Good governance is the result of, rather than a prerequisite for good forest management. (Khanal and Kandel, (2004). CFUGs have induced community members to have comprehensive governance including women, Dalit, people from ethnic minorities and remote places (Bhattarai, 2011). Involvement of disadvantaged groups in planning and decision making for their authority, responsibility and accountability represents good governance practices through the CFM. This has laid strong influences on local democracy and inclusive self-governance. Through the community forestry, good governance has been applied in term of accountability, transparency and rule of laws. (Pokharel et. al., 2007). It has been a successful model in environmental governance and community-based forest management in developing countries which encompasses well-defined policies, institutions and practices. (G.C. et. al., 2016). This win-win situation of people and the government helps for the development of natural, social, economical, human and physical capital which is a strong foundation for good-governance.

\section{Control on forest fire, rampant grazing and over exploitation:-}

Destruction caused by wildfires on timber and non-timber resources as well as villagers' lives, cattle, property, livestock in the forest specially in Tarai were common in the past years. It destroys biological diversity and natural vegetation which causes soil erosion, and also induces floods and landslides. (Dahal, 2014). Previous researchers encompassed that community forestry helps on fire control and over exploitation. The greatest achievement of community forestry are control on forest fire and improvement in the forest condition in terms of greenery and tree coverage area. (Neupane et.al., 2016).

\section{Wildlife protection:-}

Restoration of degraded land and reappearance of wild animals in the forest are the result of community forest management. Community people are protecting wildlife, preventing forest fire and maintaining greenery through formulating user's group. (Neupane et. al., 2017).

\section{Result summary:-}

The review of all articles indicates significance positive changes in the society from the community forestry including visible impacts in the livelihood of people and environment. Management of the forest by community impacts on gender equity, women empowerment and also helps to reduce poverty by generating employments, increasing income and providing infrastructural support to the community. This practice also results into good governance strengthening, reversing of the rate of deforestation, forest coverage increment and density, forest offences reduction, fire control, grazing control, climate change adaptation and mitigation, conservation of watershed, soil, river bank, water springs, bio-diversity and better utilization of forest resources which are highly important factors for the social development. Through community forestry, local people take benefits of human, social, and financial capital with improving ecological condition of forests. (Dev et. al., 2003) (Ojha and Kanel, 2005) (Subedi, 2006,) (Pandey, 2013). Hence, the following benefits of the community forestry have been identified.

1. Community members actively participate to manage and protect the forest for better utilization of resources.

2. Community people are generating income from the forest products such as timber and non-timber products, herbs, and other resources, as well as credit facilities that helps to increase livelihood opportunity.

3. Women, the poor and other disadvantaged people are actively participating in the decision making process with equitable benefits sharing through the community forestry. 
4. Community forest members make plans that includes criteria and indicators guidelines for sustainable forest management, which helps to build up self-confidence, leadership capacity and raising awareness to the members.

5. From the regular monitoring and supervision, resources are being protected from illegal exploitation.

6. Wildlife hunting, forest fire, grazing, forest encroachment, over- exploitation have been controlled and degraded forest land has been restored.

7. Social capital, community infrastructures such as development of schools, roads, community building etc have been improved.

8. It has created procedural and substantive benefits including egalitarian reflection, creation of livelihood opportunity, ecological conservation, participatory action, social justice and equality.

9. Community forestry has contributed to the protection and promotion of bio-diversity.

10. It has promoted income generation and community development activities.

11. Greenery has been restored because of community forestry.

12. It has helped increase investment in the future productivity of the forest.

13. Hence, the great achievement of community forestry is that Nepal's community forestry has begun to attract international recognition.

In conclusion, this government policy has achieved high level of success as the concept community forestry led to $30 \%$ coverage of forest managed by the community. In one side, community forest has created economic benefits to community and provided social benefits to the marginalized groups. On the other, it has improved environmental quality by reducing erosion, fire, grazing, over exploitation, protecting watersheds and increased agriculture outputs. Community forestry is significantly laid positive impact on gender equity, women empowerment, poverty reduction, bio-diversity, sustainable development as well as protection of forest by better utilization of resources. This also contributes to global environment benefits by reducing deforestation, maintaining biodiversity which improves community people's welfare. Similarly, the success of CFM depends on internal and external factors such as community size, socio-economic heterogeneity, property rights structures, forest regulation acts and bylaws. These variables positively influence the relationship of community people and forest resources and create benefits to the community. This will help to create awareness in the communities and mobilize people towards achieving the goal of sustainable forest management and development.

Therefore, community forest management in Nepal is successful in terms of meeting local people's needs, improving forest conditions, restoring degraded land, addressing environmental issues and distributing equitable benefit with ecological sustainability.

\section{Acknowledgement:-}

I would like to express my sincere thanks to my supervisor, Dr. Fang Ping for her continuous supports and guidelines for the research. She provided me with important materials and encouraged me to explore my own belief and ideas. I also want to thank my friends for their continuous supports. My special thanks go to Ramesh K. Neupane, Nabin Timalsina and Gayatra Devi Ghimire who helped me to get important data and other relevant materials along with their encouragement.

\section{References:-}

1. CBS, 2011. Statistics of population for the year 2068(2011). Central Bureau of Statistics (CBS), Government of Nepal, Kathmandu, Nepal. (1).

2. DOF, 2017. Community Forestry Bulletin, 2073 (2017). Department of Forests (DOF), Government of Nepal, Ministry of Forest and Soil Conservation, Kathmandu, Nepal. (2).

3. Bhattarai Binod, 2016. Community forest and forest management in Nepal. American journal of environmental protection. Vol.4(3),79-91. (3).

4. Maharjan K.L. Community participation in forest resource management in Nepal. Graduate School for International Development and Cooperation, Hiroshima University, Higashi-Hiroshima., 194-206. (4).

5. G.C. Dhurba Bijaya, S.Cheng, Z.Xu, J.Bhandari, L.Wang and X. Liu, 2016. Community forestry and livelihood in Nepal: A review paper, The journal of animal \& plant sciences, 26(1), 1-12. (5).

6. Pokharel B.K., Braney P., M. Nurse and Malla Y.B., 2007. Community forestry: Conserving forests, sustaining livelihoods and strengthening democracy. Journal of forest and livelihood 6(2), 8-19.

7. Bromley, D. W. 1989. Economic interests and institutions: The conceptual foundations of public policy. 
Oxford, UK: Basil Blackwell.

8. Pandey Shiva Shankar, Geoff Cockfield, Tek Narayan Maraseni, 2016. Assessing the roles of community forestry in Climate change mitigation and adaptation: A case Study From Nepal. Forest ecology and management 360, 400-407.

9. MOF, 2016. Economic Survey: Fiscal year 2015/16. Ministry of Finance (MOF), the Government of Nepal, Kathmandu, Nepal.

10. Oliver Springate-Baginski, Om Prakash Dev, Nagendra Prasad Yadav, John Soussan, 2003. Community forest management in the middle hills of Nepal: the changing context. Journal of forest and livelihood, 3 (1), 5-20.

11. Pagdee A., Kim Y.S., Daugherty P.J., 2006. What makes community forest management successful: A MetaStudy from community forests throughout the world. Society and natural resources (19):33-52.

12. Wagle Mohan and Ojha Hemant (2002). Analyzing participatory trends in Nepal's community forestry, Policy trend report. Ministry of forest and soil conservation, Nepal. Page no. 122-142.

13. Shrestha U. B., Shrestha B.B. and Shrestha Sujata, 2010. Biodiversity conservation in community forests of Nepal: Rhetoric and reality. Review, International journal of biodiversity and conservation Vol.2(5) 99-104. (23)

14. Dahal D.S., 2014. A Review article on status and trends in forests and forestry development in Nepal: Major Success and Constraints. International journal of sciences 3 (5), 52-65

15. Dahal D. S., Cao S., 2015. Sustainability assessment of community forests practices in Nepal: Literature review and recommendations to improve community management. The national academy of sciences, Dol (10) 0627-5.

16. Liu J. and Innes J.L.,2015. Participatory forest management in china: Key challenges and ways forward. International forestry review. Vol.17(2)2015

17. Kanel K. R. and Kandel B. R., 2004. Community forestry in Nepal: Achievements and challenges. Journal of forest and livelihood. 55-63.

18. Neupane R. K., Wenying X., Zhigang L., Oskenbayeva A. and Nyyssonen V.,2017. Evaluating impact of community management in forest conservation: A study on community forestry in Nepal. International journal of advance research (IJAR),5(3) 701-711.

19. Forest act 1993, Department of Forests (DOF), Government of Nepal, Ministry of Forest and Soil Conservation, Kathmandu, Nepal. (2).

20. Pokharel R.K., Suvedi M., 2007. Indicator for measuring the success of Nepal's community forestry program: A local perspective. Research in human ecology review, Vol.14(1).

21. Wade, R. 1988. Village republics: Economic conditions for collective action in South India. Oakland, CA: ICS Press.

22. Baland, J.M. and J.P. Platteau. 1996. Halting degradation of natural resources: Is there a role for rural communities? Oxford, UK: Clarendon Press.

23. Baland, J.-M. and J.-P. Platteau. 1999. The ambiguous impact of inequality on local resource management. World Dev. 27(5):773-788.

24. Hanna, S. and M. Munasinghe. 1995a. Property rights and the environment: Social and ecological Issues. Washington, DC: ESD.

25. Hanna, S. and M. Munasinghe. 1995b. Property rights in a social and ecological context: Case studies and design applications. Washington, DC: ESD.

26. Ostrom, E. 1999. Self-governance and forest resources. Occasional Paper No. 20. Jakarta, Indonesia: CIFOR.

27. Pye Smith, C., G. Borrini Feyerabend, and R. Sandbrook. 1994. The wealth of communities: stories of success in local environmental management. London: Earthscan.

28. Harini N., Karmacharya M. and Karna.(2005). Ecology and society. Evaluating forest management in Nepal: Views across space and time. 10(1):24.

29. Acharya K.P., 2004. Does community forests management support biodiversity conservation? Evidences from two community forests from the mid hills of Nepal. Journal of forests and livelihood 4(1).

30. MFSC, 2011. State of Nepali's forest. Ministry of Forests and Soil Conservation, (MFSC). Department of forest research and survey, forest resource assessment Nepal.

31. MFSC, 2015. State of Nepali's forest. Ministry of Forests and Soil Conservation, (MFSC). Department of forest research and survey, forest resource assessment Nepal.

32. Acharya K., Gentle P., 2006. Improving the effectiveness of collective action: sharing experiences from community forestry in Nepal. CGIAR system-wide program on collective action and property rights.

33. Adhikari U., 2011. Status of community forest and women. For the partial fulfilment of the requirement for the degree of masters in population, gender and development, Pokhara University, Nepal. 
34. Leone, M. (2013). Women as Decision Makers in Community Forest Management: Evidence from Nepal.

35. Tachibana T. and Adhikari S.,2007. Care Nepal Lalitpur, Nepal. Does Community-based Management improve natural resource condition? Evidence from the forest in Nepal.

36. Ojha H.R., Subedi B.P., Dhungana H., Paudel D. Citizen participation in forest Governance: Insights from community forestry in Nepal. page no. 1-10.

37. G.C. D.B., Sheng-kui C., Qijie G., Xu Z., Wang L. Bhandari J. Liu Xiaojie, Gao Liwei and Cao Xiaochang(2015). Can community forestry play a major role in the socio-economic enhancement of poor users in Nepal? Bulgarian Journal of Agricultural Science, 21(378-383).

38. Bhattarai R.C., 2011. Economic impact of community forestry in Nepal: A case of mid-hill districts of Nepal. Economic Journal of development issues vol. 13 \&14. 75-96.

39. Pandey G.S. \& Paudyal B.R., 2015. Community forestry in Nepal. Fern Protecting forests, improving livelihoods. page no.1-20

40. Paudel N.R.,Fuwa N., Otsuka K., 2014. The impacts of a community forestry program on forest conditions, management intensity and revenue generation in the Dang district of Nepal. Environment and development economics. page no. 259-281.

41. Pokharel B.K. and Nurse M. 2004. Forest and people's livelihood: Benefiting the poor from community forestry. Journal of forest and livelihood 4(1).

42. Dev O.P., Yadav N.P., Baginski O.S., Soussan J., 2003. Impacts of community forestry on livelihoods in the middle hills of Nepal. Journal of forest and livelihood 3(1).

43. Ojha HR, Cameron J, Kumar C (2009). Deliberation or symbolic violence? The governance in community forestry in Nepal. For. Pol. Econ. (doi:10.1016/j.forpol.2008.11.003)

44. Pokharel and Tumbahangphe 1999. Community forestry development action: A synthesis of NUKCFP reports and publications. NUKCFP report, Kathmandu, Nepal.

45. Ram Chandra Bhattarai 2011. Economic impact of community forestry in Nepal: A case of mid-hill districts of Nepal. Economic journal of development issues vol.13\&14, 1-2.

46. Pokharel, B.K., \& Carter, J. (2007). Addressing chronic poverty and spatial poverty traps in Nepal's middle hills: the Nepal Swiss Community Forestry Project. Paper presented at the International Conference on Chronic and Spatial Poverty. Cape Town, South Africa, March 27, 2007.

47. MSFP (2011). Economic appraisal. Multi-stakeholder forestry program (MSFP) Nepal.

48. Klooster D. \& Masera O. 2000. Community forest management in Mexico: carbon mitigation and biodiversity conservation through rural development. Global environment change, (10), 259-272.

49. Bhattacharya, P., Pradhan L., and Yadav G. (2010), 'Joint forest management in India: experiences of two decades’, Resources, Conservation, and Recycling 54(8): 469-480. 